\title{
Researches Regarding the Fatty Acids Content in Turkey Meat
}

\author{
Paul C. BOIŞTEANU, Marius M. CIOBANU, Roxana LAZĂR \\ Department of Fundamental Sciences in Animal Husbandry, University of Agricultural Sciences and \\ Veterinary Medicine, 3 Mihail Sadoveanu Alley, 700490 Iaşi, Romania \\ *Corresponding author, email: lazarrxn24@yahoo.com
}

Bulletin UASVM Animal Science and Biotechnologies 71(2) / 2014,

Print ISSN 1843-5262; Electronic ISSN 1843-536X

DOI: 10.15835/buasvmcn-asb:10816

\begin{abstract}
The lipid content of the poultry meat reveals both in domestic and wild birds a greater quantities of unsaturated fatty acids (UFA), [oleic acids (C18:1) are dominating in all tissues] comparing to the saturated fatty acids (SFA). Previous studies have shown that during the development of fat deposits there is observed an increasing of SFA and MUFA comparing to PUFA, with an impact on the decline of PUFA content and consequently of the PUFA/SFA; similar results were highlighted also in our study.

The extraction of meat lipid fraction was performed according to the protocol described by Folch. The working method used in this case was specific for the lipid separation in meat samples with a weight of $\sim 2.5 \mathrm{~g}$.

Detection of methyl esters was performed using a gas chromatograph GC Carlo Erba 5300 mega series, connected to a flame ionization detector and to a splitted injector. For $1 \mu \mathrm{L}$ sample analysis, a capillary column Omegawax 320 (Supelcco inc., Bellafonte, PA.) with highly polar stationary phase, type SP-2380 - $60 \mathrm{~m}$ length and $0.25 \mathrm{~mm}$ thickness was used.

The quantitative and qualitative description of fatty acids profile of turkey meat lipids revealed a wide range of variation, the mean of main lipid fractions have shown a predominantly content in C16:0, C18:0 for SFA, C18:1 $\omega-9$

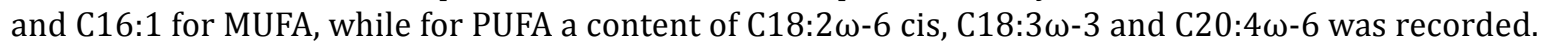

Keywords: extraction, fatty acids, turkey meat

\section{INTRODUCTION}

Compared to other species, the turkey meat has exceptional qualities, representing a source of high quality proteins, low in fats with a high level of unsaturated fatty acids.

One of the main reasons for an increased consumption of turkey meat consists in the perception that it would be low in fats and a good source that promotes a healthy diet (Mozdziak, 2004).

The total lipid content in turkey meat tissues increases with the age. The fat is a very valuable component of meat, due to its influence on the flavorings and its ability to improve the taste (Guerrero-Legarreta and Hui, 2010).

Turkey skin contains more fat than meat does, having a major contribution in fat proportion of the comestible portions.

The fatty acids have been associated with various human diseases, particularly cardiovascular diseases, with the most conclusive evidences suggesting that saturated fatty acids (SFA) may have negative consequences in human health, while the polyunsaturated fatty acids (PUFA) have beneficial effects (Cortinas et al., 2005). The fatty acids composition in turkey meat is not well documented, thus this field is presenting a high interest.

\section{MATERIALS AND METHODS}

The biological material was represented by broiler hybrid "Big B.U.T. 6", while the experimental 
groups were randomly constituted with a number of 30 birds, exploited and slaughtered by the SC Galli-Gallo SRL, Codlea. The experimental groups (L1 and L2) were differentiated by slaughtering age: 16 weeks and 20 weeks, respectively.

The quantitative demonstration of the fatty acids types from the lipid fraction of the analyzed meat collected from different anatomical regions (breast and thigh with skin) was performed on samples in duplicate.

The extraction of meat lipid fraction was performed according to the protocol described by Folch (Folch et al., 1957; Christie, 1998; Ruiz et al., 2004). The working method used in this case was specific for the lipid separation in thawed meat samples $\left(24 \mathrm{~h}\right.$ at $\left.0-4^{\circ} \mathrm{C}\right)$, with a weight of $\sim 2.5 \mathrm{~g}$ per sample. The sample weighing and the subsequent addition of 10-15 mg of internal standard (nondecanoic acid -C19:0) was performed using an analytical balance.

For lipid extraction a solvent represented by chloroform solution (99.93\%) - methanol (99\%), in a ratio of 2: 1 was used, considering that for each meat sample processing a volume of 20 times higher than the weight of the sample is required (2.5 g x $20 \mathrm{~mL}=50 \mathrm{~mL})$. During extraction steps, a rapid homogenization of meat samples for 2 minutes at $1200 \mathrm{rpm}$ using Ultra Turrax homogenizer was performed in order to ensure a complete penetration of the solvent and a complete lipid extraction from the tested samples. To conserve the resulting lipid fraction it has been resorted to its solubilisation in $2 \mathrm{~mL} 95 \%$ Hexane and subsequently stored in $8 \mathrm{~mL}$ tubes at $-20^{\circ} \mathrm{C}$.

The methylation reaction of lipid fractions included the using of $\mathrm{HCl}$ (Christie, 2003), with the main goal the conversion of the volatile fatty acids in methyl esters, detected by gas- chromatography analysis.

The protocol started with the collection of 100 mg total lipids extracted from each meat sample, which were methylated with $3 \mathrm{~mL}$ of acetyl chloride hydrochloride solution, freshly prepared $\left(\mathrm{C}_{2} \mathrm{H}_{3} \mathrm{ClO} 99 \%, 1: 10 \mathrm{v} / \mathrm{v}\right)$, over which it has been subsequently added $2 \mathrm{~mL}$ hexane, followed by solution homogenization.

At the end of two hours, a series of successively steps were performed: the addition of $5 \mathrm{~mL} \mathrm{~K} 2 \mathrm{CO}$ $36 \%$, homogenization by vortexing, stand for 30 minutes as a result of the addition of $\mathrm{Na}_{2} \mathrm{SO}_{4}$, centrifugation for 10 minutes at $2500 \mathrm{rpm}$, solvent evaporation with $\mathrm{N}_{2}$ la $40^{\circ} \mathrm{C}$, collection of the upper phase with a Pasteur pipette and transferring into a new tube. Finally, the extracted methyl esters were resuspended in $2 \mathrm{~mL}$ Hexane and stored at $-20^{\circ} \mathrm{C}$, until the gas chromatography reading.

Detection of methyl esters was performed using a gas chromatograph GC Carlo Erba 5300 mega series, connected to a flame ionization detector and to a splitted injector. For $1 \mu \mathrm{L}$ sample analysis, a capillary column Omegawax 320 (Supelcco inc., Bellafonte, PA.) with highly polar stationary phase, type SP-2380 -60 m length and $0.25 \mathrm{~mm}$ thickness was used. The running software of chromatographic analysis included a thermal working program between 160 and $250^{\circ} \mathrm{C}$, with a gradual increase of $4^{\circ} \mathrm{C} /$ minute and dividing ratio of $1: 20$.

The flame ionization detector and injector temperature was constantly maintained at $150^{\circ} \mathrm{C}$.

\section{RESULTS AND DISCUSSION}

By calculating the statistical estimators corresponding to turkey meat SFA content, obtained by slaughtering the birds at 16 and 20 weeks, the coefficient of variation for each saturated fatty acid varied between $2.75 \%$ and $37.18 \%$.

By calculating the percentage of saturated fatty acids at the level of the pectoral muscles from both experimental groups, a superiority of palmitic acid (C16:0) in L1 group was highlighted. However, $\mathrm{C} 16: 0$ is the most commonly seen saturated acid in food, responsible for an increased cholesterol, in this case ranging between $18.53 \pm 0.247 \%$ and $24.61 \pm 0.102 \%$, being lower delimited by thigh muscles and upper by breast muscles from L1 group. The second saturated fatty acid found in a high proportion is represented by the stearic acid (C18:0), the upper values characterizing the L2 experimental group for breast $(11.84 \pm 0.322 \%)$ and L1 group for thigh $(8.13 \pm 0.403 \%)$ (Tab. 1).

With respect to the muscle composition in monosaturated fatty acids, it is observed that the pectoral muscle records higher values for C14:1 (0.34 $\pm 0.023 \%), \mathrm{C} 17: 1(0.57 \pm 0.018 \%), \mathrm{C} 18: 1 \omega 7$ (1.74 $\pm 0.046 \%), \mathrm{C} 20: 1 \omega 9(0.47 \pm 0.018 \%)$, except C16: 1 and C18: $1 \omega 9$, which are specific for thigh muscles.

After calculating the degree of significance of differences existing between the experimental groups L1 and L2 through the values of each fatty 
acid corresponding to the analyzed muscles, the values have shown that monounsaturated lipids of turkey meat are quantitatively influenced by both anatomical region and the stage of fattening (Table 1,2).

Regarding the quantities in polyunsaturated fatty acids, the turkey meat has been described in a wide range of variations, the upper lipid fraction being represented by C18:2 $\omega 6$ cis through the value range of $29.03 \pm 0.251 \%$ and $38.21 \pm 0.226 \%$ out of the total FA.

The linoleic acid reduces the activity of the lipoprotein lipase, enzyme necessary for adipocytes to extract the fat from blood vessels and in the same time promotes the burning of fat in the body. For this reason, the turkey meat is recommended in diets and for a healthy lifestyle.

Another polyunsaturated fatty acid found in a high proportion in the muscle of turkey meat

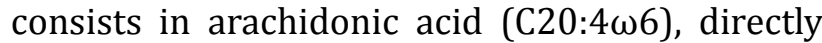
responsible for triggering the metabolism of prostaglandin in muscle and the accumulation of muscle mass. The pectoral muscle represents an important source in this polyunsaturated fatty acid, with quantitative upper values of $6.47 \pm 0.143 \%\left(\mathrm{~L}_{2}\right)$ and $4.97 \pm 0.066 \%\left(\mathrm{~L}_{1}\right)$.

Following the gas chromatographic analysis of turkey meat obtained at different slaughter ages, a downward trend in the PUFA content was observed, while for SFA and MUFA content a slight increase was seen.

The content of PUFA from the total fatty acids corresponding to the pectoral muscle and to the thigh collected from turkeys slaughtered at 16 and 20 weeks, was included in a value range shown by the lower limit $33.29 \pm 0.219 \%$ and $43.87 \pm 0.088 \%$; the lows and the highest values are characterizing thigh muscles of L2 and the breast muscles of L1.

The average values of monounsaturated fatty acids of the total lipids from turkey meat were represented by the lowest limits of the L1 $(18.22 \pm 0.065 \%)$ group breast muscles and by the upper limits of the L2 $(37.64 \pm 0.235 \%)$ group thigh muscles.

The existing lipid quality in turkey meat has been reported using the percentage of PUFA out of

Tab. 1. Fatty acid content (\%) of turkey meat

\begin{tabular}{|c|c|c|c|c|}
\hline & \multicolumn{2}{|c|}{$L_{1}$ (hatching 16 weeks) } & \multicolumn{2}{|c|}{$\mathrm{L}_{2}$ (hatching 20 weeks) } \\
\hline & BREAST & THIGH & BREAST & THIGH \\
\hline $\mathrm{C} 8: 0$ & $0.21 \pm 0.002^{\mathrm{aB}}$ & $0.04 \pm 0.001^{\mathrm{d}}$ & $0.23 \pm 0.004^{\mathrm{aA}}$ & $0.04 \pm 0.005^{\mathrm{d}}$ \\
\hline C10:0 & $0.39 \pm 0.005^{\mathrm{a}}$ & $0.11 \pm 0.004^{\mathrm{dB}}$ & $0.40 \pm 0.005^{\mathrm{a}}$ & $0.07 \pm 0.001^{\mathrm{dA}}$ \\
\hline $\mathrm{C} 12: 0$ & $0.21 \pm 0.006^{\mathrm{aB}}$ & $0.06 \pm 0.002^{\mathrm{d}}$ & $0.25 \pm 0.010^{\mathrm{aA}}$ & $0.03 \pm 0.002^{\mathrm{d}}$ \\
\hline C14:0 & $0.46 \pm 0.006 b^{c}$ & $0.59 \pm 0.013^{\mathrm{aA}}$ & $0.53 \pm 0.012^{\mathrm{A}}$ & $0.45 \pm 0.014^{\mathrm{C}}$ \\
\hline C14:1 & $0.34 \pm 0.023^{\mathrm{aA}}$ & $0.07 \pm 0.008 \mathrm{~d}$ & $0.01 \pm 0.006^{\mathrm{bD}}$ & $0.06 \pm 0.003^{a}$ \\
\hline $\mathrm{C} 15: 0$ & $0.40 \pm 0.035^{\mathrm{aA}}$ & $0.01 \pm 0.001^{\mathrm{dC}}$ & $0.01 \pm 0.004^{\mathrm{dD}}$ & $0.06 \pm 0.002^{\mathrm{aA}}$ \\
\hline C16:0 & $24.61 \pm 0.102^{\mathrm{a}}$ & $18.53 \pm 0.247^{\mathrm{bB}}$ & $22.62 \pm 0.297$ & $20.41 \pm 0.187^{\mathrm{A}}$ \\
\hline C16:1 & $1.59 \pm 0.058^{\mathrm{bB}}$ & $1.73 \pm 0.036^{\mathrm{aC}}$ & $1.65 \pm 0.029^{\mathrm{aA}}$ & $2.84 \pm 0.077^{\mathrm{cA}}$ \\
\hline C17:0 & $0.25 \pm 0.002$ & $0.22 \pm 0.006^{\mathrm{A}}$ & $0.23 \pm 0.004^{\mathrm{a}}$ & $0.14 \pm 0.006^{\mathrm{bC}}$ \\
\hline $\mathrm{C} 17: 1$ & $0.57 \pm 0.018^{\mathrm{aA}}$ & $0.19 \pm 0.004^{\mathrm{dD}}$ & $0.02 \pm 0.002^{\mathrm{dD}}$ & $0.31 \pm 0.011^{\mathrm{aA}}$ \\
\hline C18:0 & $11.18 \pm 0.106^{\mathrm{a}}$ & $8.13 \pm 0.403^{c}$ & $11.84 \pm 0.322^{\mathrm{a}}$ & $7.73 \pm 0.072^{\mathrm{c}}$ \\
\hline $\mathrm{C} 18: 1 \omega 9$ & $13.86 \pm 0.076^{\mathrm{cC}}$ & $26.38 \pm 0.467^{\mathrm{Da}}$ & $20.61 \pm 0.317^{\mathrm{dA}}$ & $32.79 \pm 0.236^{\mathrm{aA}}$ \\
\hline $\mathrm{C} 18: 1 \omega 7$ & $1.39 \pm 0.036^{\mathrm{aC}}$ & $0.95 \pm 0.048^{\mathrm{cD}}$ & $1.74 \pm 0.046^{\mathrm{aA}}$ & $1.35 \pm 0.012^{\mathrm{bA}}$ \\
\hline 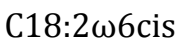 & $33.79 \pm 0.155$ & $38.21 \pm 0.226^{A}$ & $29.97 \pm 0.203$ & $29.03 \pm 0.251^{\mathrm{D}}$ \\
\hline C20:0 & $0.19 \pm 0.004^{\mathrm{aA}}$ & $0.07 \pm 0.004^{\mathrm{cD}}$ & $0.02 \pm 0.006^{\mathrm{dD}}$ & $0.15 \pm 0.002^{\mathrm{aA}}$ \\
\hline $\mathrm{C} 18: 3 \omega 6$ & $0.34 \pm 0.021^{\mathrm{aA}}$ & $0.08 \pm 0.012^{d}$ & $0.08 \pm 0.004^{\mathrm{D}}$ & $0.05 \pm 0.001$ \\
\hline $\mathrm{C} 18: 3 \omega 3$ & $0.68 \pm 0.041^{\mathrm{dA}}$ & $0.92 \pm 0.056^{\mathrm{aD}}$ & $0.58 \pm 0.023^{\mathrm{dC}}$ & $2.04 \pm 0.033^{\mathrm{aA}}$ \\
\hline $\mathrm{C} 20: 1 \omega 9$ & $0.47 \pm 0.018^{\mathrm{aA}}$ & $0.15 \pm 0.020^{\mathrm{dC}}$ & $0.04 \pm 0.010^{\mathrm{dD}}$ & $0.30 \pm 0.012^{\mathrm{aA}}$ \\
\hline C20:2 & $0.05 \pm 0.002^{\mathrm{d}}$ & $0.33 \pm 0.025^{\mathrm{aA}}$ & $0.03 \pm 0.012$ & $0.01 \pm 0.004^{\mathrm{D}}$ \\
\hline $\mathrm{C} 20: 3 \omega 3$ & $0.26 \pm 0.009^{\mathrm{aA}}$ & $0.04 \pm 0.004^{\mathrm{dA}}$ & $0.06 \pm 0.009^{\mathrm{bD}}$ & $0.01 \pm 0.002^{\mathrm{aB}}$ \\
\hline $\mathrm{C} 20: 4 \omega 6$ & $4.97 \pm 0.066^{\mathrm{aA}}$ & $2.20 \pm 0.115^{\mathrm{dA}}$ & $6.47 \pm 0.143^{\mathrm{aC}}$ & $1.35 \pm 0.012^{\mathrm{dB}}$ \\
\hline C20:5w3 & $2.26 \pm 0.102^{\mathrm{aA}}$ & $0.08 \pm 0.004^{\mathrm{dB}}$ & $1.71 \pm 0.047^{\mathrm{aC}}$ & $0.28 \pm 0.002^{\mathrm{dA}}$ \\
\hline $\mathrm{C} 22: 5 \omega 6$ & $0.92 \pm 0.030^{\mathrm{aA}}$ & $0.53 \pm 0.031^{\mathrm{cA}}$ & $0.51 \pm 0.037^{\mathrm{aB}}$ & $0.07 \pm 0.003^{\mathrm{dD}}$ \\
\hline $\mathrm{C} 22: 5 \omega 3$ & $0.42 \pm 0.021^{\mathrm{a}}$ & $0.20 \pm 0.016^{\mathrm{d}}$ & $0.37 \pm 0.050^{\mathrm{a}}$ & $0.22 \pm 0.005^{\mathbf{b}}$ \\
\hline $\mathrm{C} 22: 6 \omega 3$ & $0.18 \pm 0.004$ & $0.10 \pm 0.009^{c}$ & $0.20 \pm 0.020$ & $0.25 \pm 0.011^{\mathrm{A}}$ \\
\hline
\end{tabular}

Note: between muscle area, within each lot: ${ }^{\text {ab }} \mathrm{P}<0.05$; ${ }^{\text {ac }} \mathrm{P}<0.01$; ${ }^{\text {ad }} \mathrm{P}<0.001$

between ages, within muscle area: ${ }^{\mathrm{AB}} \mathrm{P}<0.05$; ${ }^{\mathrm{AC}} \mathrm{P}<0.01$; ${ }^{\mathrm{AD}} \mathrm{P}<0.001$ 
the total fatty acids, thus the range of the average values corresponded to $33.29 \pm 0.219 \%$ and $43.87 \pm 0.088 \%$, the lowest limits characterizing the thigh muscle and the upper limits characterizing the breast muscles. In the case of the analyzed muscles, the appropriate values of polyunsaturated fatty acids had a downward trend once aging.

\section{CONCLUSION}

The quality of the existing lipids in turkey meat has been reported using the percentage of total fatty acids, the upper limits being characteristic for breast muscles collected from turkey carcasses slaughtered at 16 weeks.

Tab. 2. Fatty acid content (\%) of turkey meat

\begin{tabular}{|c|c|c|c|c|}
\hline & \multicolumn{2}{|c|}{$L_{1}$ (hatching 16 weeks) } & \multicolumn{2}{|c|}{$\mathrm{L}_{2}$ (hatching 20 weeks) } \\
\hline & BREAST & THIGH & BREAST & THIGH \\
\hline AGS & $37.90 \pm 0.080^{\mathrm{a}}$ & $27.77 \pm 0.410^{\mathrm{dB}}$ & $36.06 \pm 0.295^{a}$ & $29.07 \pm 0.185^{\mathrm{cA}}$ \\
\hline AGMN & $18.22 \pm 0.065^{\mathrm{ac}}$ & $29.49 \pm 0.322^{\mathrm{dD}}$ & $24.03 \pm 0.319^{\mathrm{dA}}$ & $37.64 \pm 0.235^{\mathrm{aA}}$ \\
\hline AGPN & $43.87 \pm 0.088^{\mathrm{A}}$ & $42.74 \pm 0.310^{\mathrm{A}}$ & $39.91 \pm 0.210^{\mathrm{aB}}$ & $33.29 \pm 0.219^{\mathrm{cD}}$ \\
\hline$\omega-6$ & $40.02 \pm 0.124^{\mathrm{A}}$ & $41.07 \pm 0.325^{A}$ & $36.97 \pm 0.142^{\mathrm{aB}}$ & $30.48 \pm 0.196^{\mathrm{cD}}$ \\
\hline$\omega-3$ & $3.80 \pm 0.098^{\mathrm{aA}}$ & $1.34 \pm 0.049^{\mathrm{dD}}$ & $2.92 \pm 0.087^{\mathrm{bD}}$ & $2.80 \pm 0.041^{\mathrm{aA}}$ \\
\hline AGPN/AGS & $1.16 \pm 0.004^{\mathrm{b}}$ & $1.54 \pm 0.030^{\mathrm{aC}}$ & $1.11 \pm 0.012^{\mathrm{b}}$ & $1.15 \pm 0.012^{\mathrm{aA}}$ \\
\hline$(\omega-6) /(\omega-3)$ & $10.59 \pm 0.296^{\mathrm{dB}}$ & $30.98 \pm 1.250^{\mathrm{aA}}$ & $12.76 \pm 0.326^{\mathrm{aA}}$ & $10.92 \pm 0.140^{\mathrm{bD}}$ \\
\hline
\end{tabular}

Note: between muscle area, within each lot: ${ }^{\text {ab }} \mathrm{P}<0.05$; ${ }^{\text {ac }} \mathrm{P}<0.01$; ${ }^{\text {ad }} \mathrm{P}<0.001$

between ages, within muscle area: ${ }^{\mathrm{AB}} \mathrm{P}<0.05 ;{ }^{\mathrm{AC}} \mathrm{P}<0.01 ;{ }^{\mathrm{AD}} \mathrm{P}<0.001$

\section{REFERENCES}

1. Christie WW (1998). Gas chromatography-mass spectrometry methods for structural analysis of fatty acids, Lipids, 33(4): 343-353.

2. Christie WW (2003). Lipid extraction, storage and sample handling, in: Lipid Analysis, 91, $3^{\text {rd }}$ Ed., The Oily Press, Bridgwater, U.K.

3. Cortinas L, Barroeta A, Villaverde C, Galobart J, Guardiola F, Baucells MD (2005). Influence of the dietary polyunsaturation level on chicken meat quality: lipid oxidation. Poultry Science 6(1): 48-55.

4. Folch J, Lee M, Stanley GS (1957). A simple method for the isolation and purification of total lipids from animal tissues. The Journal of Biological Chemistry 226: 497-509.
5. Guerrero-Legarreta I, Hui YH (2010). Handbook of Poultry Science and Technology. vol. 1: Primary Processing, John Wiley \& Sons Publisher Inc., ISBN 978-0-470-18552-0, Hoboken, New Jersey, USA.

6. Mozdziak P (2004). Species of meat animals/poultry, in: Jenser WK, ed., Encyclopedia of Meat Science. New York: Elsevier, 1296-1302.

7. Ruiz J (2004). Improvement of a solid phase extraction method for analysis of lipid fractions in muscle foods. Analytica Chimica Acta 520: 201. 